\title{
Apoptosis-inducing factor downregulation increased neuronal progenitor, but not stem cell, survival in the neonatal hippocampus after cerebral hypoxia-ischemia
}

\author{
Yanyan Sun ${ }^{1,2,3+}$, Yu Zhang ${ }^{1,2+}$, Xiaoyang Wang ${ }^{2,4}$, Klas Blomgren ${ }^{1,5,6}$ and Changlian Zhu ${ }^{1,2^{*}}$
}

\begin{abstract}
Background: A considerable proportion of all newly generated cells in the hippocampus will die before becoming fully differentiated, both under normal and pathological circumstances. The caspase-independent apoptosis-inducing factor (AIF) has not been investigated previously in this context.

Results: Postnatal day 8 (P8) harlequin (Hq) mutant mice, expressing lower levels of AlF, and wild type littermates were injected with BrdU once daily for two days to label newborn cells. On P10 mice were subjected to hypoxia-ischemia $(\mathrm{HI})$ and their brains were analyzed $4 \mathrm{~h}, 24 \mathrm{~h}$ or 4 weeks later. Overall tissue loss was $63.5 \%$ lower in $\mathrm{Hq}$ mice 4 weeks after $\mathrm{HI}$. Short-term survival ( $4 \mathrm{~h}$ and $24 \mathrm{~h}$ ) of labeled cells in the subgranular zone was neither affected by AIF downregulation, nor by HI. Long-term (4 weeks) survival of undifferentiated, BLBP-positive stem cells was reduced by half after $\mathrm{HI}$, but this was not changed by AIF downregulation. Neurogenesis, however, as judged by BrdU/NeuN double labeling, was reduced by half after $\mathrm{HI}$ in wild type mice but preserved in $\mathrm{Hq}$ mice, indicating that primarily neural progenitors and neurons were protected. A wave of cell death started early after $\mathrm{HI}$ in the innermost layers of the granule cell layer (GCL) and moved outward, such that $24 \mathrm{~h}$ after $\mathrm{HI}$ dying cells could be detected in the entire GCL.

Conclusions: These findings demonstrate that AIF downregulation provides not only long-term overall neuroprotection after $\mathrm{HI}$, but also protects neural progenitor cells, thereby rescuing hippocampal neurogenesis.
\end{abstract}

Keywords: Apoptosis-inducing factor, Apoptosis, Asphyxia, Hippocampus, Neurogenesis, Cell proliferation

\section{Background}

Perinatal asphyxia-induced brain injury is one of the most common causes of mortality and long term neurological impairment (cerebral palsy, mental retardation, visual as well as hearing impairment, learning disability and epilepsy) in term and preterm neonates [1]. A significant breakthrough was that post-insult hypothermia within 6 hours reduced severe disability, including cerebral palsy [2]. Other milestones in the field were the

\footnotetext{
* Correspondence: changlian.zhu@neuro.gu.se

†Equal contributors

${ }^{1}$ Center for Brain Repair and Rehabilitation, Institute of Neuroscience and Physiology, Sahlgrenska Academy, University of Gothenburg, Gothenburg, Sweden

${ }^{2}$ Department of Pediatrics, The Third Affiliated Hospital of Zhengzhou University, Zhengzhou, China

Full list of author information is available at the end of the article
}

findings that low dose rhEPO treatment [3] or delayed hypothermia up to 10 hours [4] reduce the risk of disability in infants with moderate term hypoxic-ischemic encephalopathy. Current therapeutic options for preterm hypoxic-ischemic brain injury are limited and predominantly supportive, to maintain physiological parameters.

Hypoxia-ischemia (HI) causes opposite reactions of injury and repair. On the one hand, HI leads to neuronal, including neural stem/progenitor cell (NSPC), death and brain injury by excessive production of free radicals, excitatory amino acids, inflammation as well as mitochondrial dysfunction [1]. The patterns of neuronal cell death after $\mathrm{HI}$ involve necrosis, apoptosis and autophagy, based on biochemical and morphological criteria, and accumulating data show that mixed morphological phenotypes often are observed [5-9]. The immature brain retains its apoptotic

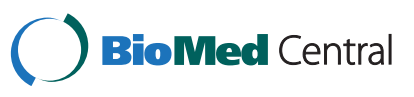


machinery to a larger extent than the adult brain, at least as judged by caspase- 3 activation [10-13]. There are two distinct pathways leading to nuclear apoptosis, caspasedependent and caspase-independent. Caspases are a class of cysteine proteases that mediate apoptotic death in a variety of cellular systems. Caspases are activated after HI, particularly in the immature brain [12]. Consequently, caspase inhibition affords neuroprotection in the immature brain $[14,15]$. Recent data demonstrate that when caspase activation is inhibited at or downstream of the apoptosome, neurons can undergo a delayed, caspaseindependent death [16]. One of the key components of the caspase-independent cell death pathway is apoptosis-inducing factor (AIF) which, when released from mitochondria, translocates to the nucleus and induces large-scale DNA fragmentation and cell death [17]. Inhibition or depletion of AIF can provide neuroprotection in vitro and in vivo $[14,18,19]$. HI also activates protective and restorative mechanisms. For example, HI up-regulates erythropoietin (EPO) and other growth/ trophic factors and induces NSPC proliferation and differentiation [20]. Proliferating cells migrate to the injury [21-23], even very long after the insult [24,25], inspiring hope for tissue repair and plasticity. However, a related problem is the poor survival of the newly generated NSPCs after ischemic insults [26]. More than 90\% of newborn cells die within one month [27]. Therefore, exploring death mechanisms of endogenous NSPCs will provide important information for prevention/inhibition of NSPC death and hopefully promote brain repair. The purpose of this study was to evaluate the effects of AIF downregulation on neuronal and NSPC death after HI in the immature brain as well as long-term effects on brain injury.

\section{Results}

\section{AIF downregulation reduced $\mathrm{HI}$ brain injury}

Brain injury was evaluated on P38, 4 weeks after $\mathrm{HI}$ (Figure 1A). The injury encompasses the cortex, hippocampus, striatum and thalamus (Figure 1B). The overall tissue loss, including infarction and subsequent atrophy, was $21.3 \pm 5.6 \mathrm{~mm}^{3}(\mathrm{n}=14)$ in Wt mice and $7.8 \pm 2.2 \mathrm{~mm}^{3}$ $(\mathrm{n}=11)$ in Hq mutant mice, which corresponds to a $63.5 \%$ reduction $(\mathrm{P}=0.002)$ (Figure $1 \mathrm{C})$.

\section{AIF downregulation had no effect on short-term proliferation and survival}

Cell proliferation in the subgranular zone (SGZ) was assessed $4 \mathrm{~h}$ and $24 \mathrm{~h}$ after $\mathrm{HI}$ by BrdU labeling 1 and 2 days before HI (Figure 1A). This means that the labeled cells were born 1 or 2 days before $\mathrm{HI}$ and survived at least until $4 \mathrm{~h}$ or $24 \mathrm{~h}$ after HI. Neither the HI insult nor the Hq mutation had any obvious short-term effect on the number of BrdU-labeled cells in the SGZ (Figure 2A, 2B).
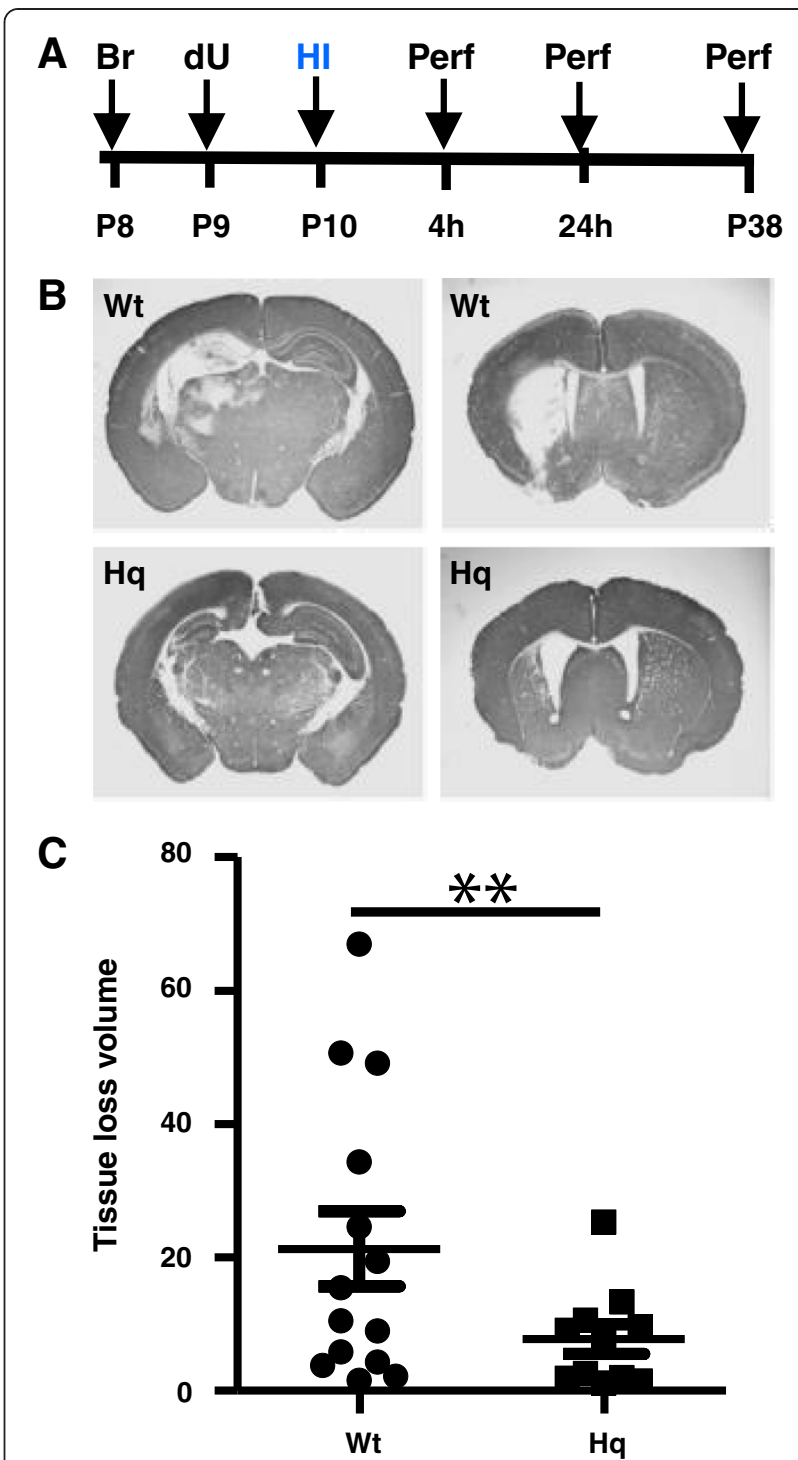

Figure 1 AIF down regulation reduced $\mathrm{HI}$ brain injury. A. The study design. B. Representative MAP2 stainings from the levels of dorsal hippocampus (left panels) and striatum (right panels) 4 weeks post-HI of wild type (Wt) (upper panels) and Harlequin mutant (Hq) mice (lower panels). $\mathbf{C}$. The total tissue loss volume 4 weeks after $\mathrm{HI}$ was reduced by $63.5 \%$ in $\mathrm{Hq}$ mice $(n=11)$ as compared with Wt mice $(n=14)$. ${ }^{* *} P<0.01$.

AIF downregulation increased neuronal progenitor, but not stem cell, survival

Cells in the SGZ expressing brain lipid binding protein (BLBP) are undifferentiated, radial glia-like neural precursors [28]. The number of BLBP-labeled cells in the SGZ was not different between Wt and Hq mice, neither in control brains, nor after hypoxia-ischemia (Figure 3A, 3B). The total number of surviving BrdU-labeled cells per GCL in the control was $5359 \pm 456$ in Wt $(n=5)$ and $6210 \pm 541$ in $\mathrm{Hq}(\mathrm{n}=6)$ brains after 4 weeks (n.s.). However, the number 


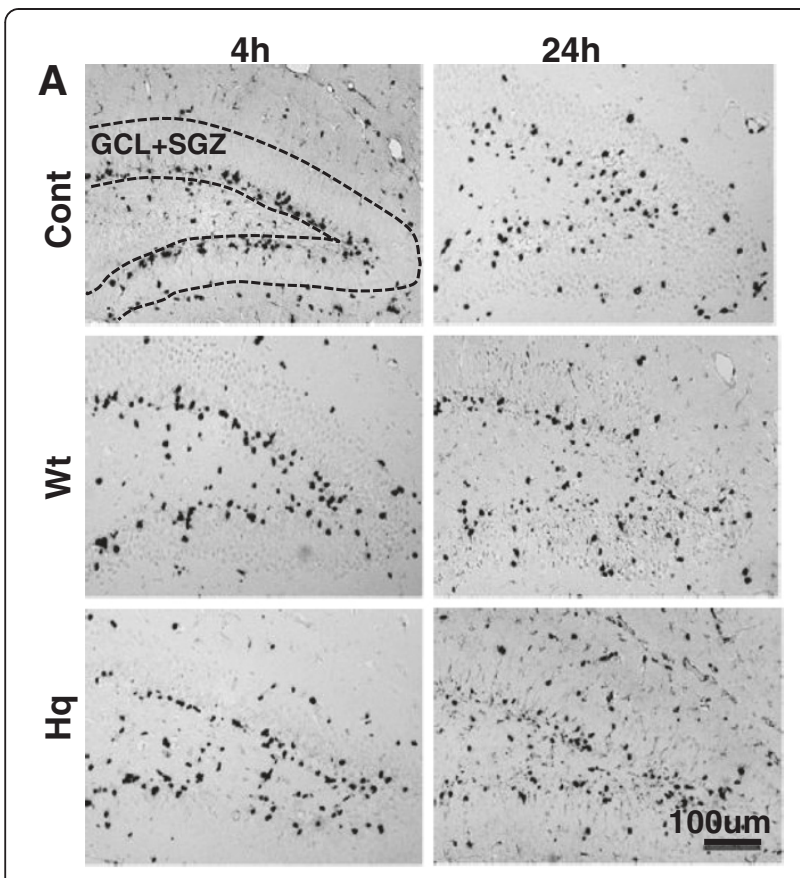

B

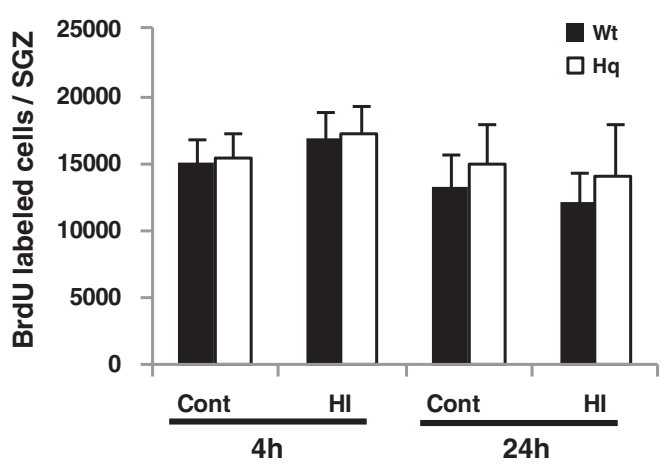

Figure 2 Cell proliferation in the DG after HI. A. Representative microphotographs of BrdU stainings in the DG in naiive controls (top panels), at $4 \mathrm{~h}$ (left panels) and $24 \mathrm{~h}$ (right panels) after HI. B. The bar graph shows quantification of the total number of BrdU-positive cells in the SGZ in controls (Cont) and ipsilateral hemisphere after $\mathrm{HI}$ in Wt and Hq mice $4 \mathrm{~h}$ ( $\mathrm{n}=5$ or 8 for Wt and Hq controls, $\mathrm{n}=6$ or 7 for Wt and $\mathrm{Hq}$ $\mathrm{HI}$ ) and $24 \mathrm{~h}(\mathrm{n}=6$ or $8 \mathrm{Wt}$ and $\mathrm{Hq}$ controls, $\mathrm{n}=7$ or 8 for Wt and $\mathrm{Hq} \mathrm{HI}$ ).

of BrdU-labeled cells surviving 4 weeks after HI was higher in $\mathrm{Hq}$ than Wt brains $(\mathrm{p}=0.030)$. In Wt mice, the number decreased $40.1 \%$, to $3209 \pm 605(\mathrm{p}=0.013)$, whereas in $\mathrm{Hq}$ mice the decrease was only $17.6 \%$, to $5115 \pm 532$ (n.s.) (Figure 3C, 3D). The phenotyping of newly generated cells surviving 4 weeks showed that about $70 \%$ developed into neurons, as judged by $\mathrm{BrdU} / \mathrm{NeuN}$ double labeling (Figure 3E, 3F), and this ratio was the same in $\mathrm{Wt}$ and $\mathrm{Hq}$ animals, both in non-ischemic control and HI brains. Importantly, while the number of labeled cells surviving 4 weeks after $\mathrm{HI}$ and differentiating into neurons decreased approximately $45 \%$ in Wt mice, it was not significantly decreased in Hq mice (Figure 3F). The number of newly generated astrocytes, as indicated by BrdU/S100 double labeling was not different, neither between genotypes, nor between control and HI mice (data not shown).

AIF downregulation reduced cell death in the dentate gyrus Cell death in the hippocampus was investigated by detecting DNA strand breaks (TUNEL), necrosis (FBDP), as well as caspase-dependent (active caspase-3) and -independent (nuclear AIF) apoptosis [12]. The number of positive cells was counted in the GCL + SGZ $4 \mathrm{~h}$ and $24 \mathrm{~h}$ after HI (Figure 4). Interestingly, early after HI ( $4 \mathrm{~h})$ dying cells, as judged by TUNEL, active caspase-3 and nuclear AIF, were mainly detected in the inner layers of the GCL, whereas later $(24 \mathrm{~h})$ after the insult dying cells could be detected throughout the GCL (Figure 4A). Necrotic (FBDP-positive) cells, though, were mainly detected in the outer layers of the GCL, in differentiated neurons rather than immature NSPCs, both $4 \mathrm{~h}$ and $24 \mathrm{~h}$ after HI (Figure 4). The total number of dying cells was higher in Wt mice, particularly $24 \mathrm{~h}$ after HI (Figure 4D). There were no AIF-positive cells, displaying nuclear AIF, in Hq mice (Figure 4).

\section{AIF downregulation reduced newborn cell death}

Death of newly generated cells was detected by combining BrdU staining with the cell death markers TUNEL or active caspase- $34 \mathrm{~h}$ and $24 \mathrm{~h}$ after HI (Figure 5A). The total number of TUNEL/BrdU double-positive cells in the SGZ was $2691 \pm 894$ in the Wt mice and $731 \pm 186(\mathrm{n}=6)$ in the Hq mice $(n=7)(p=0.041) 4 \mathrm{~h}$ after HI. The total number of active caspase-3/BrdU double-positive cells was also lower in $\mathrm{Hq}$ mice $(453 \pm 197)$ compared with Wt mice $(1229 \pm 304)(p=0.0498)$ (Figure $5 B)$. In the Hq mice, fewer cells were dying, but the overall numbers of BrdU-labeled cells in the SGZ $4 \mathrm{~h}$ and $24 \mathrm{~h}$ after HI were not different between $\mathrm{Hq}$ and wild type mice, as shown above (Figure 2B). The double-positive cells were fewer in the SGZ $4 \mathrm{~h}$ than $24 \mathrm{~h}$ after $\mathrm{HI}$ and no significant differences between Wt and Hq mice were observed (data not shown).

\section{AIF downregulation reduced pathological microglia activation}

The total numbers of microglia in the immature Wt or $\mathrm{Hq}$ brains were not different, according to Iba-1 immunostaining and quantification (Figure 6A, 6B). Galectin-3, a marker of pathological microglia activation [29], was not detected in the normal control brains, it was detected only in injured areas, as expected (Figure 6A). The number of galectin3 -positive cells was lower in the $\mathrm{Hq}$ mice than in Wt mice after HI (Figure 6C). Some of the activated microglia were observed engulfing dying cells, as judged by TUNEL-positive chromatin fragments inside these cells (Figure 6D). 

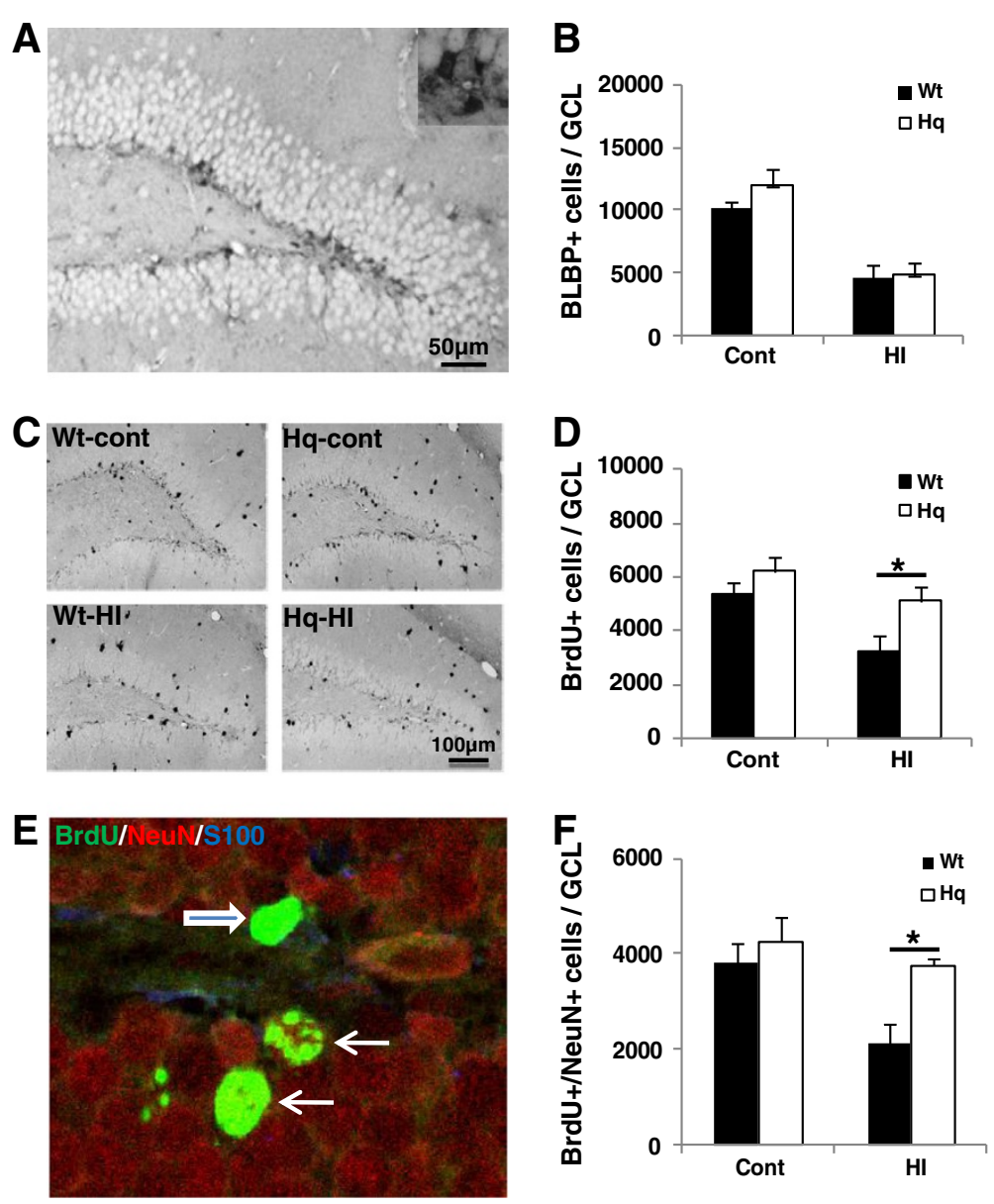

Figure 3 Survival and differentiation of proliferated cells in the DG 4 weeks after HI. A. Representative microphotograph of BLBP staining in the DG 4 weeks after HI. B. The bar graph shows quantification of the total number of BLBP-positive cells in the SGZ. C. Representative microphotographs after BrdU staining in the DG at 4 weeks after HI. D. Quantification of BrdU-positive cells in the DG (GCL + SGZ) in the control (Cont) and ipsilateral hemisphere after $\mathrm{HI}$ in Wt and $\mathrm{Hq}$ mice. E. Representative microphotograph showing triple labeling of BrdU/NeuN/S100 in the DG. F. Quantification of the number of BrdU/NeuN double-positive cells (neurons) in DG (GCL) in the control (Cont) and ipsilateral hemisphere after $\mathrm{HI}$ in Wt and $\mathrm{Hq}$ mice. ${ }^{*} \mathrm{P}<0.05$.

\section{Discussion}

Apoptosis is important during normal brain development [30,31]. Our previous studies have shown that apoptotic cell death after $\mathrm{HI}$ in the immature brain involves caspasedependent and -independent pathways [14]. Caspases are activated after HI, particularly in the immature brain [12] and caspase inhibition affords neuroprotection in the immature brain [14,15,32]. A causal role of AIF for neuronal cell death and brain injury following $\mathrm{HI}$ in the immature brain has been identified by using $\mathrm{Hq}$ mutant mice, where brain injury was reduced by $52.6 \%$ at 3 days after HI [14]. In this study we demonstrate long-term neuroprotection in AIF-deficient mice after $\mathrm{HI}$, where brain injury was reduced by as much as $63.5 \% 4$ weeks after HI. This extends our earlier findings and further confirms that AIF plays a major role in the development of brain injury after
HI. After HI, a large proportion of the dying neurons in the immature brain are immunopositive for both active caspase-3 and nuclear AIF, but there are also populations of neurons displaying only active caspase- 3 or only nuclear AIF [18]. We found that $\mathrm{Hq}$ mice displayed approximately $50 \%$ smaller infarct volumes than wild type mice. The caspase inhibitor Q-VD-OPh also produced approximately $50 \%$ smaller infarct volumes, and combining the two, by treating $\mathrm{Hq}$ mice with Q-VD-OPh, produced an additional $50 \%$ infarct volume reduction [14]. Also in a model of traumatic brain injury in adult mice, increased protection was found when combining functional AIF reduction (as in cyclophilin $A^{-/-}$mice) with caspase inhibition (bocAsp-FMK) [33]. Hence, caspase-dependent and caspaseindependent (AIF-dependent) pathways appear to act, at least partly, in parallel. 

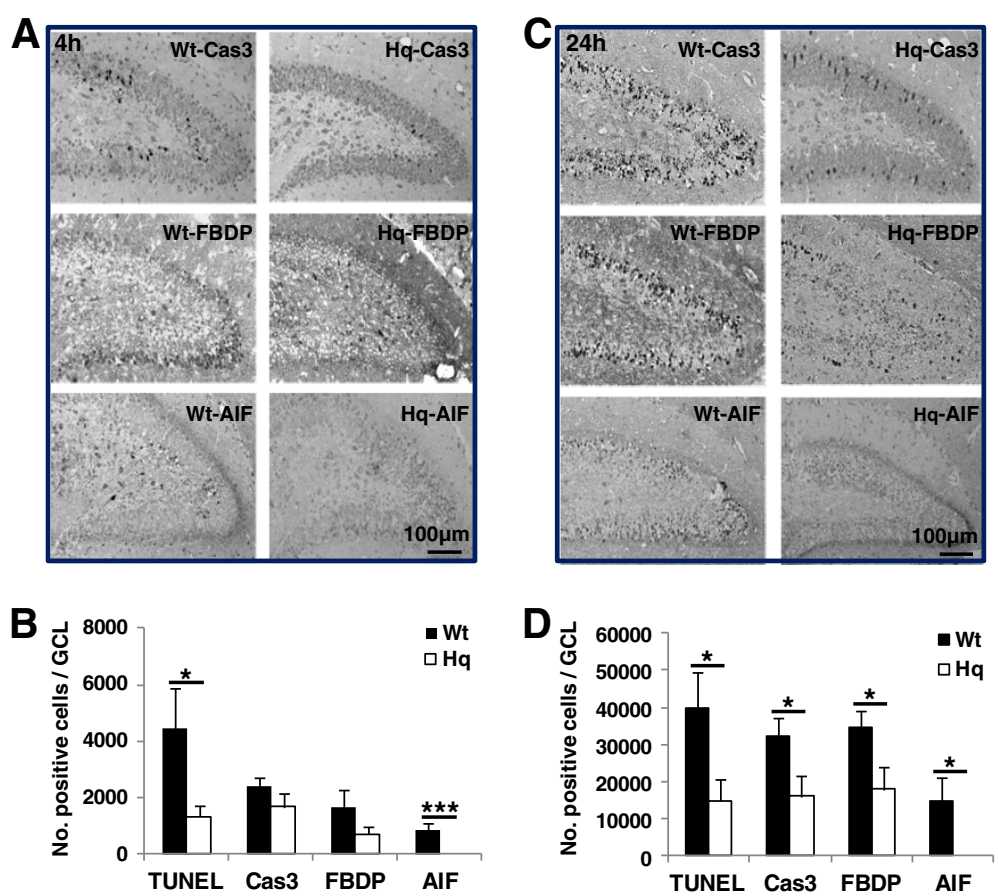

Figure 4 Cell death in the DG after HI. A. Representative stainings of active caspase-3, FBDP and AIF in the DG of Wt (left panel) and Hq (right panel) mice $4 \mathrm{~h}$ after HI. B. The bar graph shows the quantification of positive cells for each cell death-related marker in the GCL at $4 \mathrm{~h}$ after $\mathrm{HI}$. C. Representative stainings of active caspase-3, FBDP and AlF in the DG of Wt (left panel) and Hq (right panel) mice $24 \mathrm{~h}$ after HI. D. The bar graph shows the quantification of positive cells for each cell death-related marker in the GCL at $24 \mathrm{~h}$ after $H{ }^{*} \mathrm{P}<0.05$, ${ }^{* * *} \mathrm{P}<0.001$.

Opposite its role in mediating apoptosis once it is released from mitochondria, AIF, as a flavoprotein, is essential for the maintenance of a fully functional complex I [34]. In healthy cells, the physiological role of AIF in sustaining complex I-driven oxidative phosphorylation appears related to the local redox activity of AIF and is independent of its proapoptotic properties [35]. Efforts to study the mitochondrial function of AIF have focused on the putative ability of AIF to regulate reactive oxygen species [36]. Genetic mutant $\mathrm{Hq}$ mice with up to $80 \%$ reduction of mitochondrial AIF, display reduced levels of complex I and impaired assembly of complex I subunits [37]. These mice exhibit mitochondrial respiratory chain diseases, such as cerebellar neurodegeneration with ataxia and progressive retinal degeneration. A recent study showed that the mitochondrial complex I contributes to oxidative injury during early reperfusion after $\mathrm{HI}$ in the neonatal mouse brain and that inhibition of complex I decreased the extent of $\mathrm{HI}$ injury [38]. The $\mathrm{Hq}$ mutation, displaying reduced levels of AIF, but also reduced levels of for example catalase and complex I, renders the brain tissue more susceptible to oxidative stress [14,37]. We did not assess the levels of oxidative stress in the SGZ in this study, but it would be interesting to evaluate the effects of an antioxidant agent, to see if the effects in the SGZ would be different from the effects in mature neurons.
Interestingly, we observed a wave of apoptotic cell death starting at the inner layers of the GCL and moving outwards, and at the same time increasing about 10 -fold in numbers of dying cells from $4 \mathrm{~h}$ to $24 \mathrm{~h}$ after HI (Figure 4). Necrotic cell death, as judged by massive calcium influx leading to calpain-specific cleavage of fodrin to yield the $150 \mathrm{kDa}$ breakdown product (FBDP), was only observed in the outer layers of the GCL, indicating that necrosis occurred only in fully differentiated neurons, not in stem and progenitor cells. Only a fraction of the BrdU-labeled cells in the inner layers of the GCL died (underwent apoptosis) after HI. This means that out of all the BrdU-labeled cells in the SGZ, born 1 or 2 days earlier and surviving until $4 \mathrm{~h}$ after HI, approximately $16 \%$ were TUNEL-positive and $7 \%$ were active caspase-3-positive (compare Figures $2 \mathrm{~B}$ and $5 \mathrm{~B}$ ). In the $\mathrm{Hq}$ mice, approximately $70 \%$ fewer cells were dying (were TUNEL-positive) in the SGZ after HI, but the overall numbers of BrdU-labeled cells (dying and not dying) in the SGZ $4 \mathrm{~h}$ and $24 \mathrm{~h}$ after HI were not different between $\mathrm{Hq}$ and wild type mice (Figure 2B). The double-positive cells were fewer in the SGZ $24 \mathrm{~h}$ than $4 \mathrm{~h}$ after $\mathrm{HI}$ and no significant differences between Wt and $\mathrm{Hq}$ mice were observed (data not shown). As noted above, by this time point $(24 \mathrm{~h})$ the wave of cell death had spread outward and, consequently, fewer dying, 

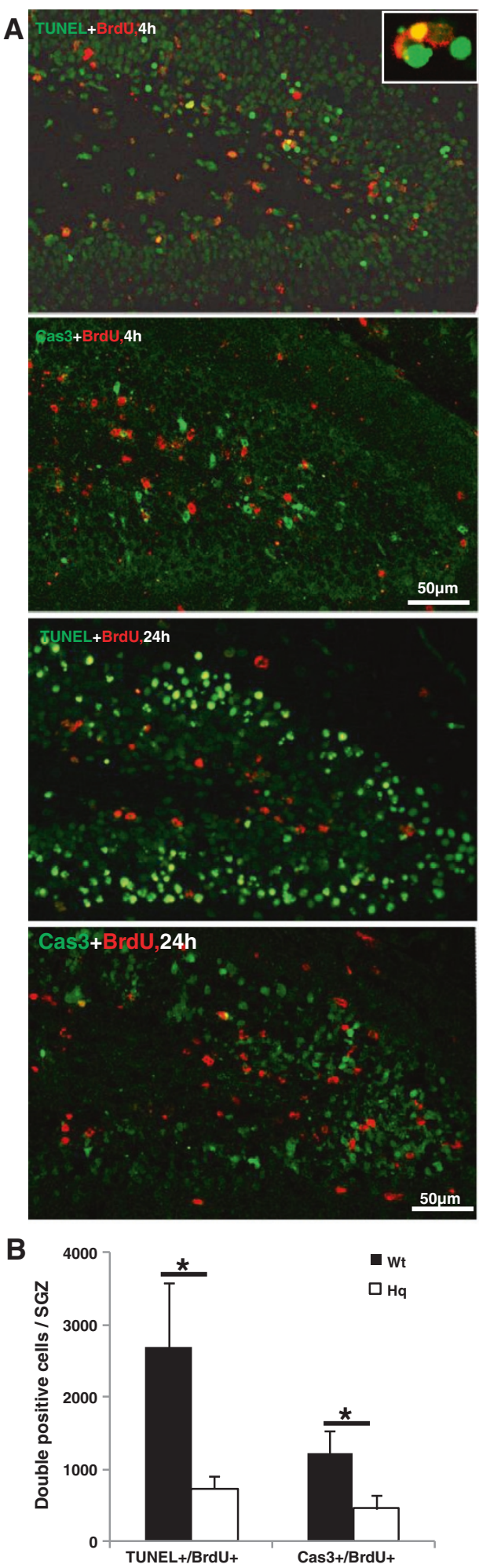

Figure 5 Double labeling of BrdU and cell death markers after HI. A. Representative double labelings of BrdU with the cell death-related markers TUNEL and active caspase-3 in the DG $4 \mathrm{~h}$ and $24 \mathrm{~h}$ after $\mathrm{HI}$. B. The number of dying newborn cells in the SGZ, as indicated by double labeling $4 \mathrm{~h}$ after $\mathrm{HI}$, was lower in the Hq mice. ${ }^{*} \mathrm{P}<0.05$. newly generated cells could be detected in the inner layers (SGZ), even though the total number of dying cells was approximately 10 times higher in the entire GCL at this later time point. It is not clear why the apparently lower rate of dying cells in the SGZ in Hq mice did not lead to a difference in undifferentiated, BLBPpositive cells 4 weeks later (Figure 2A, 2B). Presumably, the AIF downregulation only protected neuronally committed progenitor cells and neurons, not undifferentiated stem cells. Also, as mentioned above, it was only a fraction of the BrdU-labeled cells that were TUNEL- or active caspase-3-positive, and only a fraction of these that was protected by the AIF deficiency. Nevertheless, the loss of a number of undifferentiated as well as more or less differentiated cells after HI leads to impaired growth of the DG, resulting in a smaller DG volume 5 weeks after HI, as shown earlier [39]. Overall, we have shown that AIF plays an important role not only in the HI-induced death of mature neurons throughout the brain, but also in the HI-induced death of newborn cells and neuronal progenitors in the DG.

Neurogenesis can be induced by brain ischemia, indicating that regenerative mechanisms are activated by injurious stimuli. This could inspire hope for development of restorative therapies for neurological disorders and brain injuries. However, the majority of newborn cells appearing after $\mathrm{HI}$ do not survive beyond 3 weeks, as judged by BrdU-labeling [26,27]. Since immature cells are more prone to undergo apoptosis than fully differentiated neurons, particularly in the immature brain, we propose that the continuous and massive decrease in the number of BrdU-labeled cells induced by an injury may be due to apoptosis-mediated cell death, which in turn reduces the restorative capacity. A previous study showed that stem and progenitor cells in the subventricular zone die after $\mathrm{HI}$ at least partly through caspase-3 and calpain activation [6]. Under normal conditions in the adult hippocampus, the majority of newborn cells undergo death by apoptosis in the first 1 to 4 days of life, during the transition from amplifying neuroprogenitors to neuroblasts [40]. In the present study, we followed the fate of cells born 1 or 2 days before HI, i.e. when they were changing from transient amplifying cells to neuroblasts. Reducing apoptosis through overexpression of bcl-2 under the neuron-specific enolase (NSE) promoter was found to double the rate of neurogenesis in the dentate gyrus as demonstrated by quantification of doublecortin-positive progenitor cells and BrdU/ NeuN double-labeling. The effect of Bcl-2 was limited to the late phase of progenitor maturation, presumably correlating with the onset of NSE expression, as proliferation and early-phase progenitor cells were not affected and the increased level of neurogenesis led to a significantly higher total number of granule cells in the 

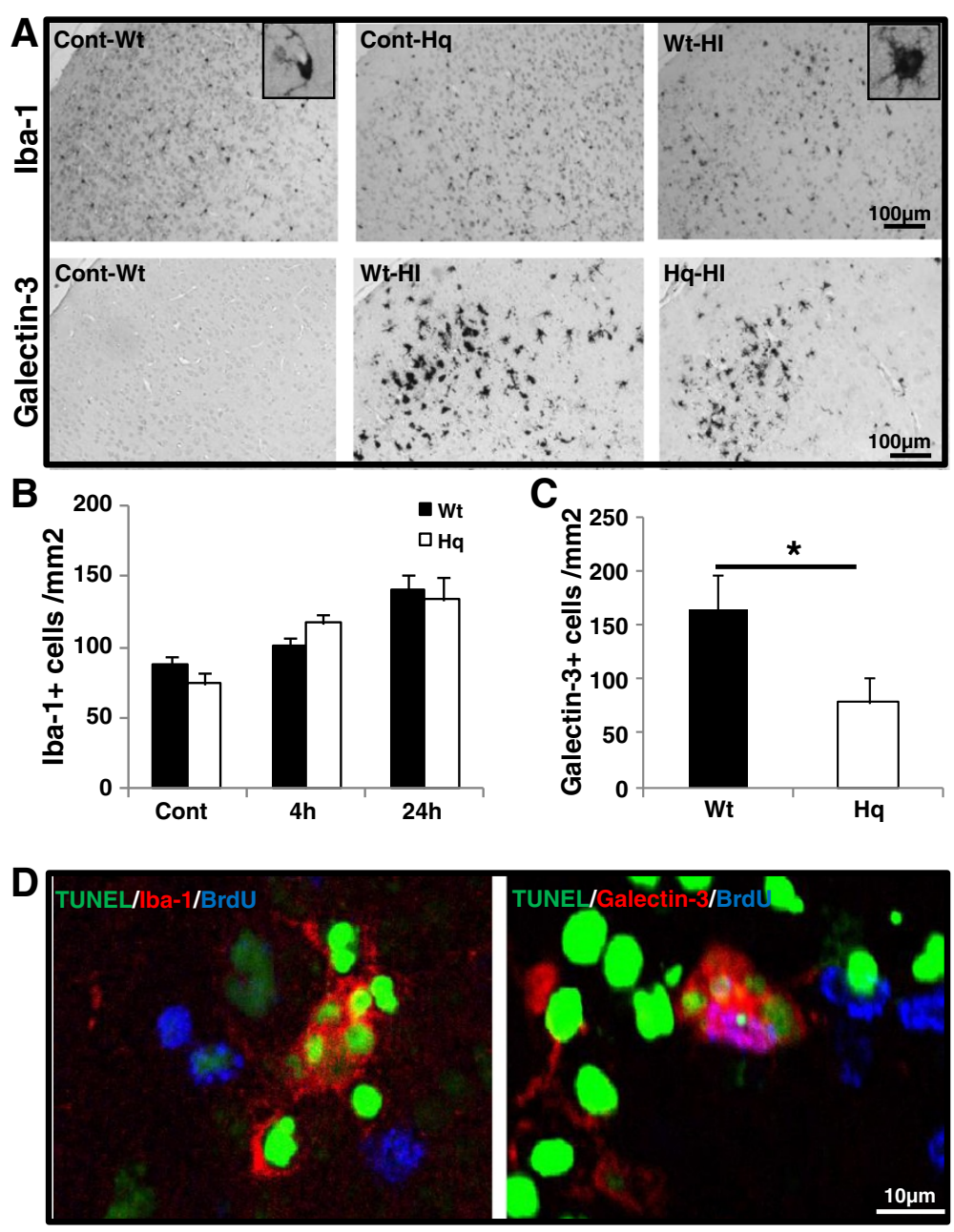

Figure 6 Microglia activation after HI. A. Representative Iba-1 (upper panel) and galectin-3 (lower panel) immunostainings in the cortex of both Wt and $\mathrm{Hq}$ control brains and $24 \mathrm{~h}$ after HI. B. Quantification of Iba-1-positive cells in the cortex did not show any difference between Wt and Hq mice. C. Quantification of galectin-3-positive cells in the cortex $24 \mathrm{~h}$ after Hl showed fewer pathologically activated microglia in the Hq mice. D. Triple labeling with TUNEL, BrdU and Iba-1 or galectin-3 $24 \mathrm{~h}$ after HI showing Iba-1- or galectin-3-positive cells engulfing dead cells (TUNEL-positive chromatin fragments).

dentate gyrus [41]. Pharmacological caspase inhibition could increase the number of surviving, seizure-induced newborn neurons [42]. The role of AIF in the death of newborn cells after $\mathrm{HI}$ in the immature brain has not been investigated before. In this study, we found evidence for AIF-induced cell death both in the early phase of transient amplifying cells/early neuroblasts as well as in the later phase of mature neuronal progenitors and young neurons.

\section{Conclusions}

In summary, this study demonstrates that AIF plays a role in the wave of apoptotic cell death extending from the inner layers of the GCL outward and that downregulation of AIF could rescue hippocampal neurogenesis.

\section{Materials and methods}

\section{Induction of $\mathrm{HI}$ brain injury}

Postnatal day 10 (P10) wild type or Harlequin mutant (Hq) mouse pups were anesthetized with isoflurane (5\% for induction, $1.5-3.0 \%$ for maintenance) in a mixture of nitrous oxide and oxygen (1:1); the duration of anesthesia was less than $5 \mathrm{~min}$. The left common carotid artery was cut between double ligatures of prolene sutures (6.0). After the surgical procedures the wounds were infiltrated with lidocaine for analgesia. The pups were returned to their dams for $60 \mathrm{~min}$ and then placed in a chamber perfused with a humidified gas mixture (10\% oxygen in nitrogen) for $45 \mathrm{~min}$ at $36^{\circ} \mathrm{C}$ to induce a mild brain injury [12]. Following hypoxic exposure, the pups were returned to their dams until sacrifice. Control pups were neither subjected 
to ligation nor hypoxia. All animal experimentation was approved by the Gothenburg Committee of the Swedish Animal Welfare Agency (145-2008).

\section{BrdU administration}

The thymidine analog 5-bromo-2-deoxyuridine (BrdU) (Roche, Mannheim, Germany, $5 \mathrm{mg} / \mathrm{mL}$ dissolved in $0.9 \%$ saline) was prepared freshly prior to use and injected intraperitoneally $(50 \mathrm{mg} / \mathrm{kg})$ on $\mathrm{P} 8$ and $\mathrm{P} 9$, before HI (Figure 1A).

\section{Injury evaluation}

Brain injury was evaluated by the volume of total hemispheric tissue loss, as judged by MAP2 immunostaining. The MAP2-positive and -negative areas in each section were measured using Micro Image (Olympus, Japan). The tissue volume was calculated from the MAP2-positive areas according to the Cavalieri principle using the following formula: $\mathrm{V}=\Sigma \mathrm{A} \times \mathrm{P} \times \mathrm{T}$, where $\mathrm{V}=$ total volume, $\Sigma \mathrm{A}=$ sum of area measurements, $\mathrm{P}=$ the inverse of the sampling fraction, and $\mathrm{T}=$ the section thickness. The total hemispheric tissue loss was calculated as the MAP2-positive volume in the contralateral hemisphere minus the MAP2-positive volume in the ipsilateral hemisphere.

\section{Immunohistochemistry}

The animals were anesthetized and perfusion-fixed with $5 \%$ formaldehyde in 0.1 M PBS. The paraffin-embedded brains were serial cut in $5 \mu \mathrm{m}$ coronal sections and mounted on glass slides. On the hippocampus level, every $50^{\text {th }}$ section was stained. Antigen retrieval was performed by heating the sections in $10 \mathrm{mM}$ boiling sodium citrate buffer $(\mathrm{pH}$ 6.0) for $10 \mathrm{~min}$. Nonspecific binding was blocked for $30 \mathrm{~min}$ with $4 \%$ goat or horse or donkey serum in PBS. Monoclonal rat anti-BrdU (1:100, $5 \mu \mathrm{g} / \mathrm{ml}$; clone: BU1/75, Oxford Biotechnology Ltd. Oxfordshire, UK), monoclonal mouse antiMAP-2 (1:1000, clone HM-2, Sigma, Saint Louis, Missouri, USA), rabbit anti-active caspase-3 (1:100, $10 \mu \mathrm{g} / \mathrm{ml}, \mathrm{BD}$ Pharmingen, USA), rabbit anti-FBDP (1:50), goat anti-AIF (1:100, $2 \mu \mathrm{g} / \mathrm{ml}$, sc-9416, Santa Cruz), rabbit anti-brain lipid binding protein (BLBP) (1:600, ABN14, Millipore, Temecula, CA, USA), rabbit anti-Iba-1 (1:1000, $0.5 \mu \mathrm{g} / \mathrm{ml}$, Wako, Osaka, Japan), rat anti-galectin-3 (1:100, $5 \mu \mathrm{g} / \mathrm{ml}$, eBioscience, San Diego, CA, USA) primary antibody was applied and incubated at $20^{\circ} \mathrm{C}$ for $60 \mathrm{~min}$, followed by the appropriate biotinylated secondary antibodies for $60 \mathrm{~min}$ at $20^{\circ} \mathrm{C}$. Visualization was performed using Vectastain $\mathrm{ABC}$ Elite kit (Vector Laboratories, Burlingame, CA, USA).

For TUNEL and BrdU double or triple labelings, after antigen retrieval, sections were incubated with $3 \%$ bovine serum albumin in $0.1 \mathrm{M}$ Tris- $\mathrm{HCl}(\mathrm{pH} 7.5)$ for $30 \mathrm{~min}$ followed by $50 \mu \mathrm{l}$ of TUNEL reaction mixture on each sample for $60 \mathrm{~min}$ at $37^{\circ} \mathrm{C}$ in a moisture chamber. After washing, the sections were incubated with rat anti-BrdU
(1:100, $5 \mu \mathrm{g} / \mathrm{ml}$; clone: BU1/75, Oxford Biotechnology Ltd. Oxfordshire, UK) or mouse anti-BrdU and rabbit anti-Iba-1 or mouse anti-BrdU and rat anti-galectin-3 for $60 \mathrm{~min}$ at room temperature. After washing, the sections were incubated appropriate Alexa Fluor labeled donkey anti-rat IgG $(\mathrm{H}+\mathrm{L})$ or Alexa Fluor 555 donkey antirabbit and Alexa Fluor 647 donkey anti-mouse or Alexa Fluor 555 donkey anti-rat and Alexa Fluor 647 donkey anti-mouse at $20^{\circ} \mathrm{C}$ for $60 \mathrm{~min}$. For active caspase- 3 and BrdU double labeling, rabbit anti-active caspase-3(1:100, $10 \mu \mathrm{g} / \mathrm{ml}, \mathrm{BD}$ Pharmingen, USA) and rat anti-BrdU $(1: 100,1: 100,5 \mu \mathrm{g} / \mathrm{ml})$ were incubated at $20^{\circ} \mathrm{C}$ for $60 \mathrm{~min}$. After washing, the sections were incubated with Alexa Fluor 555 donkey anti-rat IgG $(\mathrm{H}+\mathrm{L})$, combined with Alexa 488 donkey anti-rabbit IgG $(\mathrm{H}+\mathrm{L})$.

The phenotype of BrdU-labeled cells was determined using antibodies against NeuN or S100 $\beta$. The sections were incubated with rat anti-BrdU together with mouse anti-NeuN monoclonal antibody (1:200, $5 \mu \mathrm{g} / \mathrm{ml}$; clone: MAB377, Chemicon, Temecula, CA, USA) and rabbit anti-S-100ß (1:1000; Swant, Bellinzona, Switzerland) in $\mathrm{PBS}$ at $20^{\circ} \mathrm{C}$ for $60 \mathrm{~min}$. After washing, the sections were incubated with secondary antibodies, Alexa Fluor 488 donkey anti-rat IgG $(\mathrm{H}+\mathrm{L})$, combined with Alexa 555 donkey anti-mouse IgG $(\mathrm{H}+\mathrm{L})$ and Alexa 647 donkey anti-rabbit IgG $(\mathrm{H}+\mathrm{L})$ at $20^{\circ} \mathrm{C}$ for $60 \mathrm{~min}$. All secondary antibodies were from Jackson ImmunoResearch Lab and were diluted 1:500. After washing, the sections were mounted using Vectashield mounting medium.

\section{Cell counting}

The number of BrdU-labeled cells were counted in every $50^{\text {th }}$ section in the subgranular zone (SGZ) $4 \mathrm{~h}$ or $24 \mathrm{~h}$ after $\mathrm{HI}$, or in the entire granule cell layer (GCL), including the SGZ, 4 weeks after HI, using unbiased stereological counting techniques (StereoInvestigator, MicroBrightField Inc., Magdeburg, Germany). For the phenotype, at least 50 BrdU-positive cells in the GCL were phenotyped using a confocal laser scanning microscope (Leica TCS SP, Heidelberg, Germany) and the ratio of Brdu/ $\mathrm{NeuN}$ or BrdU/S100 $\beta$ double-labeled cells was calculated for each sample. The total number of neurons (BrdU/ NeuN-positive) and astrocytes (BrdU/S100 $\beta$-positive) in each sample was calculated based on the number of BrdUpositive cells and the ratio of double labeling. The BrdU and TUNEL or BrdU and active caspase-3 double-positive cells were counted in the SGZ by using confocal microscopy. The Iba-1- or galectin-3-positive cells were counted at 400x magnification in the border zone of the injured cortex within an area of $0.196 \mathrm{~mm}^{2}$. Three sections were counted from each brain with an interval of $250 \mu \mathrm{m}$. The average was used as $\mathrm{n}=1$ when comparing different brains. All the counting was carried out by investigators blinded to group assignment. 


\section{Statistical analysis}

All data are expressed as mean \pm s.e.m. Student's unpaired $t$-test was used to compare the numbers of cell death-related markers, BrdU-positive cell numbers, numbers of newborn neurons and astrocytes between the two groups. Significance was assumed when $\mathrm{p}<0.05$.

\section{Abbreviations}

AIF: Apoptosis inducing factor; BLBP: Brain lipid binding protein; BrdU: 5-bromo-2-deoxyuridine; DG: Dentate gyrus; FBDP: Fodrin brakdown product; GCL: Granule cell layer; HI: Hypoxia ischemia; Hq: Harlequin;

MAP-2: Microtubule associated protein-2; NSPC: Neural stem/progenitor cell; P: Postal day; PBS: Phosphate-buffer saline; SGZ: Subgranular zone; TUNEL: Terminal deoxynucleotidyl transferase mediated dUTP nick end-labeling; Wt: Wild type.

\section{Competing interests}

The authors declare that they have no competing interests.

\section{Acknowledgements}

This work was supported by the Swedish Research Council (K2012-99x21988-01-3, 2009-2328), the Swedish Childhood Cancer Foundation (PROJ10/ 032, PROJ11/071, FTJH06/001, FoAss09/001), The Frimurare Barnhus Foundation, Swedish governmental grants to scientists working in health care (ALF), the Aina Wallström and Mary-Ann Sjöblom Foundation for Medical Research, the Sten A Olson Foundation, the Wilhelm and Martina Lundgren Foundation, Edit Jacobsons Donations foundation, Kungl. Vetenskaps och vitterhets samhället i Göteborg, the Amlöv Foundation, the Gothenburg Medical Society, and the National Nature Science Foundation of China (30870883 to CZ)

\section{Author details}

${ }^{1}$ Center for Brain Repair and Rehabilitation, Institute of Neuroscience and Physiology, Sahlgrenska Academy, University of Gothenburg, Gothenburg, Sweden. ${ }^{2}$ Department of Pediatrics, The Third Affiliated Hospital of Zhengzhou University, Zhengzhou, China. ${ }^{3}$ Department of Pediatrics, Zhengzhou Children's Hospital, Zhengzhou, China. ${ }^{4}$ Perinatal Center, Institute of Neuroscience and Physiology, Sahlgrenska Academy, University of Gothenburg, Gothenburg, Sweden. ${ }^{5}$ Department of Pediatrics, The Queen Silvia Children's Hospital, University of Gothenburg, Gothenburg, Sweden. ${ }^{6}$ Department of Women's and Children's Health, Karolinska Institutet, Karolinska University Hospital, Stockholm, Sweden.

\section{Authors' contribution}

YS, YZ, XW and CZ performed experiments. CZ and KB conceived and designed the experiment and wrote the manuscript. $Y Z, Y Z$ and $C Z$ collected and assembled the data. All authors read and approved the final manuscript.

Received: 12 March 2012 Accepted: 25 April 2012

Published: 25 April 2012

\section{References}

1. Johnston MV, Nakajima W, Hagberg H: Mechanisms of hypoxic neurodegeneration in the developing brain. Neuroscientist 2002, 8(3):212-220.

2. Gluckman PD, Wyatt JS, Azzopardi D, Ballard R, Edwards AD, Ferriero DM, Polin RA, Robertson CM, Thoresen M, Whitelaw A, et al: Selective head cooling with mild systemic hypothermia after neonatal encephalopathy: multicentre randomised trial. Lancet 2005, 365(9460):663-670.

3. Zhu C, Kang W, Xu F, Cheng X, Zhang Z, Jia L, Ji L, Guo X, Xiong H, Simbruner $G$, et al: Erythropoietin improved neurologic outcomes in newborns with hypoxic-ischemic encephalopathy. Pediatrics 2009, 124(2): e218-e226.

4. Li T, Xu F, Cheng X, Guo X, Ji L, Zhang Z, Wang X, Blomgren K, Simbruner G, Changlian Z: Systemic Hypothermia Induced within 10 Hours After Birth Improved Neurological Outcome in Newborns with Hypoxic-Ischemic Encephalopathy. Hosp Pract (Minneap) 2009, 37(1):147-152.

5. Koike M, Shibata M, Tadakoshi M, Gotoh K, Komatsu M, Waguri S, Kawahara N, Kuida K, Nagata S, Kominami E, et al: Inhibition of autophagy prevents hippocampal pyramidal neuron death after hypoxic-ischemic injury. Am J Pathol 2008, 172(2):454-469.
6. Romanko MJ, Zhu C, Bahr BA, Blomgren K, Levison SW: Death effector activation in the subventricular zone subsequent to perinatal hypoxia/ ischemia. J Neurochem 2007, 103(3):1121-1131.

7. Liu CL, Siesjo BK, Hu BR: Pathogenesis of hippocampal neuronal death after hypoxia-ischemia changes during brain development. Neuroscience 2004, 127(1):113-123.

8. Puka-Sundvall M, Gajkowska B, Cholewinski M, Blomgren K, Lazarewicz JW, Hagberg H: Subcellular distribution of calcium and ultrastructural changes after cerebral hypoxia-ischemia in immature rats. Brain Res Dev Brain Res 2000, 125(1-2):31-41.

9. Northington FJ, Ferriero DM, Flock DL, Martin LJ: Delayed neurodegeneration in neonatal rat thalamus after hypoxia-ischemia is apoptosis. J Neurosci 2001, 21(6):1931-1938.

10. Blomgren K, Zhu C, Wang X, Karlsson JO, Leverin AL, Bahr BA, Mallard C, Hagberg $\mathrm{H}$ : Synergistic activation of caspase-3 by m-calpain after neonatal hypoxia-ischemia: a mechanism of "pathological apoptosis"? J Biol Chem 2001, 276(13):10191-10198.

11. Hu BR, Liu CL, Ouyang Y, Blomgren K, Siesjo BK: Involvement of caspase-3 in cell death after hypoxia-ischemia declines during brain maturation. $J$ Cereb Blood Flow Metab 2000, 20(9):1294-1300.

12. Zhu C, Wang X, Xu F, Bahr BA, Shibata M, Uchiyama Y, Hagberg H, Blomgren $\mathrm{K}$ : The influence of age on apoptotic and other mechanisms of cell death after cerebral hypoxia-ischemia. Cell Death Differ 2005, 12 (2):162-176.

13. Blomgren $K$, Leist $M$, Groc L: Pathological apoptosis in the developing brain. Apoptosis 2007, 12(5):993-1010.

14. Zhu C, Wang X, Huang Z, Qiu L, Xu F, Vahsen N, Nilsson M, Eriksson PS, Hagberg $H$, Culmsee $C$, et al: Apoptosis-inducing factor is a major contributor to neuronal loss induced by neonatal cerebral hypoxiaischemia. Cell Death Differ 2007, 14(4):775-784

15. Wang X, Zhu C, Hagberg H, Korhonen L, Sandberg M, Lindholm D, Blomgren $\mathrm{K}$ : X-linked inhibitor of apoptosis (XIAP) protein protects against caspase activation and tissue loss after neonatal hypoxia-ischemia. Neurobiol Dis 2004, 16(1):179-189.

16. Zhu C, Qiu L, Wang X, Hallin U, Cande C, Kroemer G, Hagberg H, Blomgren $\mathrm{K}$ : Involvement of apoptosis-inducing factor in neuronal death after hypoxia-ischemia in the neonatal rat brain. J Neurochem 2003, 86 (2):306-317.

17. Susin SA, Lorenzo HK, Zamzami N, Marzo I, Snow BE, Brothers GM, Mangion J, Jacotot E, Costantini P, Loeffler M, et al: Molecular characterization of mitochondrial apoptosis-inducing factor. Nature 1999, 397(6718):441-446.

18. Culmsee C, Zhu C, Landshamer S, Becattini B, Wagner E, Pellecchia M, Blomgren K, Plesnila N: Apoptosis-inducing factor triggered by poly (ADP-ribose) polymerase and Bid mediates neuronal cell death after oxygen-glucose deprivation and focal cerebral ischemia. J Neurosci 2005 25(44):10262-10272

19. Zhu C, Wang X, Deinum J, Huang Z, Gao J, Modjtahedi N, Neagu MR, Nilsson M, Eriksson PS, Hagberg H, et al: Cyclophilin A participates in the nuclear translocation of apoptosis-inducing factor in neurons after cerebral hypoxia-ischemia. J Exp Med 2007, 204(8):1741-1748.

20. Sun J, Zhou W, Sha B, Yang Y: Ischemia induced neural stem cell proliferation and differentiation in neonatal rat involved vascular endothelial growth factor and transforming growth factor-beta pathways. Brain Dev 2010, 32(3):191-200.

21. Nakatomi H, Kuriu T, Okabe S, Yamamoto S, Hatano O, Kawahara N, Tamura A, Kirino T, Nakafuku M: Regeneration of hippocampal pyramidal neurons after ischemic brain injury by recruitment of endogenous neural progenitors. Cell 2002, 110(4):429-441.

22. Schneider A, Kruger C, Steigleder T, Weber D, Pitzer C, Laage R, Aronowski J, Maurer MH, Gassler N, Mier W, et al: The hematopoietic factor G-CSF is a neuronal ligand that counteracts programmed cell death and drives neurogenesis. J Clin Invest 2005, 115(8):2083-2098.

23. Arvidsson A, Collin T, Kirik D, Kokaia Z, Lindvall O: Neuronal replacement from endogenous precursors in the adult brain after stroke. Nat Med 2002, 8(9):963-970

24. Thored P, Arvidsson A, Cacci E, Ahlenius H, Kallur T, Darsalia V, Ekdahl CT, Kokaia Z, Lindvall O: Persistent production of neurons from adult brain stem cells during recovery after stroke. Stem Cells 2006, 24(3):739-747.

25. Osman AM, Porritt MJ, Nilsson M, Kuhn HG: Long-Term Stimulation of Neural Progenitor Cell Migration After Cortical Ischemia in Mice. Stroke 2011, 42(12):3559-3565. 
26. Ikeda T, Iwai M, Hayashi T, Nagano I, Shogi M, Ikenoue T, Abe K: Limited differentiation to neurons and astroglia from neural stem cells in the cortex and striatum after ischemia/hypoxia in the neonatal rat brain. Am J Obstet Gynecol 2005, 193(3 Pt 1):849-856.

27. Bingham B, Liu D, Wood A, Cho S: Ischemia-stimulated neurogenesis is regulated by proliferation, migration, differentiation and caspase activation of hippocampal precursor cells. Brain Res 2005, 1058(1-2): $167-177$.

28. Suh H, Consiglio A, Ray J, Sawai T, D'Amour KA, Gage FH: In vivo fate analysis reveals the multipotent and self-renewal capacities of Sox2+ neural stem cells in the adult hippocampus. Cell Stem Cell 2007, 1(5): 515-528.

29. Li H, Li Q, Du X, Sun Y, Wang X, Kroemer G, Blomgren K, Zhu C: Lithium-mediated long-term neuroprotection in neonatal rat hypoxia-ischemia is associated with antiinflammatory effects and enhanced proliferation and survival of neural stem/progenitor cells. J Cereb Blood Flow Metab 2011, 31(10):2106-2115.

30. Kuida K, Zheng TS, Na S, Kuan C, Yang D, Karasuyama H, Rakic P, Flavell RA: Decreased apoptosis in the brain and premature lethality in CPP32-deficient mice. Nature 1996, 384(6607):368-372.

31. Oppenheim RW, Blomgren K, Ethell DW, Koike M, Komatsu M, Prevette D, Roth KA, Uchiyama Y, Vinsant S, Zhu C: Developing postmitotic mammalian neurons in vivo lacking Apaf-1 undergo programmed cell death by a caspase-independent, nonapoptotic pathway involving autophagy. J Neurosci 2008, 28(6):1490-1497.

32. Cheng Y, Deshmukh M, D'Costa A, Demaro JA, Gidday JM, Shah A, Sun Y, Jacquin MF, Johnson EM, Holtzman DM: Caspase inhibitor affords neuroprotection with delayed administration in a rat model of neonatal hypoxic-ischemic brain injury. J Clin Invest 1998, 101(9):1992-1999.

33. Piao CS, Loane DJ, Stoica BA, Li S, Hanscom M, Cabatbat R, Blomgren K, Faden Al: Combined inhibition of cell death induced by apoptosis inducing factor and caspases provides additive neuroprotection in experimental traumatic brain injury. Neurobiol Dis 2012, Epub ahead of print.

34. Mate MJ, Ortiz-Lombardia M, Boitel B, Haouz A, Tello D, Susin SA, Penninger J, Kroemer G, Alzari PM: The crystal structure of the mouse apoptosis-inducing factor AIF. Nat Struct Biol 2002, 9(6):442-446.

35. Hangen E, Blomgren K, Benit P, Kroemer G, Modjtahedi N: Life with or without AIF. Trends Biochem Sci 2010, 35(5):278-287.

36. Chinta SJ, Rane A, Yadava N, Andersen JK, Nicholls DG, Polster BM: Reactive oxygen species regulation by AIF- and complex I-depleted brain mitochondria. Free Radic Biol Med 2009, 46(7):939-947.

37. Klein JA, Longo-Guess CM, Rossmann MP, Seburn KL, Hurd RE, Frankel WN, Bronson RT, Ackerman SL: The harlequin mouse mutation downregulates apoptosis-inducing factor. Nature 2002, 419(6905):367-374.

38. Niatsetskaya ZV, Sosunov SA, Matsiukevich D, Utkina-Sosunova IV, Ratner VI, Starkov AA, Ten VS: The oxygen free radicals originating from mitochondrial complex I contribute to oxidative brain injury following hypoxia-ischemia in neonatal mice. J Neurosci 2012, 32(9):3235-3244.

39. Qiu L, Zhu C, Wang X, Xu F, Eriksson PS, Nilsson M, Cooper-Kuhn CM, Kuhn $H G$, Blomgren $\mathrm{K}$ : Less neurogenesis and inflammation in the immature than in the juvenile brain after cerebral hypoxia-ischemia. J Cereb Blood Flow Metab 2007, 27(4):785-794.

40. Sierra A, Encinas JM, Deudero JJ, Chancey JH, Enikolopov G, OverstreetWadiche LS, Tsirka SE, Maletic-Savatic M: Microglia shape adult hippocampal neurogenesis through apoptosis-coupled phagocytosis. Cell Stem Cell 2010, 7(4):483-495.

41. Kuhn HG, Biebl M, Wilhelm D, Li M, Friedlander RM, Winkler J: Increased generation of granule cells in adult $\mathrm{BCl}$-2-overexpressing mice: a role for cell death during continued hippocampal neurogenesis. Eur J Neurosci 2005, 22(8):1907-1915.

42. Ekdahl CT, Mohapel P, Weber E, Bahr B, Blomgren K, Lindvall O: Caspase-mediated death of newly formed neurons in the adult rat dentate gyrus following status epilepticus. Eur J Neurosci 2002, 16(8):1463-1471.

doi:10.1186/1750-1326-7-17

Cite this article as: Sun et al:: Apoptosis-inducing factor downregulation increased neuronal progenitor, but not stem cell, survival in the neonatal hippocampus after cerebral hypoxia-ischemia. Molecular Neurodegeneration 2012 7:17.

\section{Submit your next manuscript to BioMed Central and take full advantage of:}

- Convenient online submission

- Thorough peer review

- No space constraints or color figure charges

- Immediate publication on acceptance

- Inclusion in PubMed, CAS, Scopus and Google Scholar

- Research which is freely available for redistribution

Submit your manuscript at www.biomedcentral.com/submit
C Biomed Central 